1 Jagdeo J, Robinson L, Long T: Unusual clinical presentation of benign eccrine poroma. J Am Acad Dermatol 2005;54:733-734.

2 Goldman P, Pinkus H, Rogin JR: Eccrine poroma; tumors exhibiting features of the epidermal sweat duct unit. Arch Dermatol 1956;74:511-521.

3 Nemoto I, Akiyama N, Aoyagi S: Eccrine porocarcinoma and eccrine poroma arising in a scar. Br J Dermatol 2004;150:1232-1233.

4 Penneys NS, Ackerman AB, Indgin SN: Eccrine poroma: two unusual variants. $\mathrm{Br} \mathrm{J}$ Dermatol 1970;82:613-615.

5 Johnson RC, Rosenmeier GJ, Keeling JH: A painful step: eccrine poroma. Arch Dermatol 1992;128:1530-1533.

6 McCalmont TH: A call for logic in the classification of adnexal neoplasms. Am J Dermatopathol 1996;18:103-109.
7 Lan CC, Yu HS, Wu CS: Pigmented eccrine poroma with enhanced endothelin-1 expression: implications for mechanism of hyperpigmentation. Br J Dermatol 2005;152:10701072 .

8 Argenziano G, Soyer HP, Chimenti S, Talamini R, Corona R, Sera F, et al: Dermoscopy of pigmented skin lesions: results of a consensus meeting via the Internet. J Am Acad Dermatol 2003;48:679-693.

9 Zalaudek I, Citarella L, Soyer HP, HofmannWellenhof R, Argenziano G: Dermoscopy features of pigmented squamous cell carcinoma: a case report. Dermatol Surg 2004;30: 539-540.

10 Argenziano G, Zalaudek I, Corona R, Sera F, Cicale L, Petrillo G, et al: Vascular structures in skin tumors: a dermoscopy study. Arch Dermatol 2004; 140:1485-1489.

11 Kuo H-W, Ohara K: Pigmented eccrine poroma: a report of two cases and study with dermoscopy. Dermatol Surg 2003;29:10761079 .
12 Tachihara R, Choi C, Langley RG, Anderson $\mathrm{RR}$, Gonzalez S: In vivo confocal imaging of pigmented eccrine poroma. Dermatology 2002;204:185-189.

13 Altamura D, Piccolo D, Lozzi GP, Peris K: Eccrine poroma in an unusual site: a clinical and dermoscopic simulator of amelanotic melanoma. J Am Acad Dermatol 2005;53: 539-541.

14 Pizzichetta MA, Talamini R, Stanganelli I, Puddu P, Bono R, Argenziano G, et al: Amelanotic/hypomelanotic melanoma: clinical and dermoscopic features. Br J Dermatol 2004;150:1117-1124.

15 Blum A, Metzler G, Bauer J: Polymorphous vascular patterns in dermoscopy as a sign of malignant skin tumors: a case of an amelanotic melanoma and a porocarcinoma. Dermatology 2005;210:58-59.

\title{
Announcement
}

\section{International Board Certification in Dermatopathology}

http://www.icdermpath.org

The European Union of Medical Specialists (Union Européenne des Médecins Spécialistes = UEMS), Section of Dermato-Venereology and Section of Pathology, will organize under the auspices of the International Committee for Dermatopathology the 5th International Board Certifying Examination in Dermatopathology (Diploma in Dermatopathology) on December 8, 2007, in Frankfurt/Main, Germany.

Further details about this examination, including eligibility criteria, application form and contact informations are posted at the website http://www.icdermpath.org.

Address for correspondence:

Lorenzo Cerroni, MD

Department of Dermatology, Medical University of Graz

Auenbruggerplatz 8

AT-8036 Graz (Austria)

Tel. +433163852423, Fax +433163852466

E-Mail lorenzo.cerroni@meduni-graz.at 